\title{
KOMUNIKASI PEMBANGUNAN PEMERINTAH KULON PROGO DALAM MEMBERIKAN PEMAHAMAN KEPADA MASYARAKAT TERKAIT PEMBANGUNAN $N E W$ YOGYAKARTA INTERNASIONAL AIRPORT
}

\author{
Choirul Fajri ${ }^{1, \text { a) }}$ \\ Siti Mawadati ${ }^{2}$ \\ Anton Yudhana ${ }^{3}$ \\ ${ }^{1}$ Program Studi Ilmu Komunikasi, Universitas Ahmad Dahlan \\ ${ }^{a}$ Korespondensi ; choirul.fajri@comm.uad.ac.id \\ ${ }^{2}$ Program Studi Ilmu Komunikasi, Universitas Ahmad Dahlan \\ ${ }^{3}$ Program Studi Ilmu Komunikasi, Universitas Ahmad Dahlan
}

DOl:https://doi.org/10.18196/jkm.101012

Article Info

Article history:

Received 9 Sept 2018

Revised 19 Okt 2018

Accepted 27 Okt 2018

\section{ABSTRACT}

The plan to build a new airport in Kulon Progo still continues to get rejection from the public. Around 116 family heads still choose to stay in their homes, and refuse to be relocated. The government development communication strategy is needed to solve this problem in order to accelerate the airport development plan which is targeted to be completed in 2019. The development communication strategy is realized in the form of: socialization to the community, public consultation, lobbying and negotiation, as well as the use of communication media to provide an understanding to the community of the importance of the new airport. This research is carried out by survey method, which is distributing questionnaires to affected communities, to measure the extent to which the effectiveness of development communication by the DIY Government is related perceptions and expectations of the community itself. The results of this study indicate that there is a significant relationship between planning and socialization with people's perceptions of the construction of a new airport in Kulon Progo. The planning process that is done carefully, and development communication/socialization carried out intensely and openly has resulted in the existence of a good perception from the community related to the plan to build a new airport in Temon Kulon Progo.

Keywords: development communication; airport; Kulon Progo.

\section{ABSTRAK}

Rencana pembangunan bandara baru di Kulon Progo masih terus mendapatkan penolakan dari masyarakat. Sekitar 116 kepala keluarga masih memilih bertahan di rumahnya, dan menolak untuk direlokasi. Strategi komunikasi pembangunan dari pemerintah diperlukan untuk menyelesaikan permasalahan ini guna mempercepat rencana pembangunan bandara yang ditargetkan selesai pada tahun 2019. Strategi komunikasi pembangunan tersebut diwujudkan dalam bentuk: sosialisasi ke masyarakat, konsultasi publik, lobby dan negosiasi, serta pemanfaatan media-media komunikasi untuk memberikan pemahaman kepada masyarakat akan pentingnya bandara baru. Penelitian ini dilakukan dengan metode survei, yakni membagikan kuesioner kepada masyarakat terdampak, untuk mengukur sejauh mana efektivitas komunikasi sosial yang dilakukan Pemerintah DIY, terkait juga persepsi dan harapan dari 
masyarakat sendiri. Hasil dari penelitian ini menunjukkan adanya hubungan yang signifikan antara perencanaan dan sosialisasi dengan persepsi masyarakat mengenai pembangunan bandara baru di Kulon Progo. Proses perencanaan yang dilakukan secara matang, dan komunikasi yang dilakukan dengan intens dan terbuka telah memberikan hasil adanya persepsi baik dari masyarakat terkait dengan rencana pembangunan bandara baru di Temon Kulon Progo ini.

Kata kunci: komunikasi social; bandara; Kulon Progo

\section{PENDAHULUAN}

Rencana pembangunan bandara baru di Temon Kulon Progo sudah ada semenjak tahun 2012. Pembangunan bandara baru ini merupakan salah satu strategi pemerintah untuk meningkatkan jumlah wisatawan di Yogyakarta. Bandara Adi Sucipto sudah tidak mampu lagi menampung banyaknya wisatawan dengan jalur udara. Adi Sucipto hanya mampu menampung sekitar 1,5-2 juta penumpang/tahun, padahal jumlah penumpang saat ini mencapai 7 juta penumpang. Oleh karenanya, pembangunan bandara baru adalah sebuah keharusan yang perlu segera dilakukan. Bandara baru di Kulon Progo ditargetkan akan mulai beroperasi pada tahun 2019, dan diharapkan mampu menampung 20 juta penumpang.

Pro kontra mewarnai rencana pembangunan bandara ini. Ada yang mendukung, namun tak sedikit pula yang menolak. Masyarakat yang kontra, membentuk Kelompok Masyarakat Wahana Tri Tunggal untuk menyuarakan penolakan mereka semenjak tahun 2014 lalu. Masyarakat. Saat ini aksi penolakan tersebut memang sudah tidak terjadi lagi. Sekitar $80 \%$ masyarakat telah menerima kebijakan pemerintah untuk membangunan bandara baru, dan bersedia untuk direlokasi. Sebagian besar masyarakat telah mulai menempati rumah-rumah baru yang telah disediakan pemerintah. Proses pembayaran ganti rugipun juga telah dilakukan.

Sampai dengan sekarang proses pembangunan bandara tengah dilakukan, akan tetapi ternyata masih ada kelompok masyarakat yang tetap bersikeras menolak rencana pembangunan bandara tersebut. Sekitar 116 masyarakat, masih bertahan di rumahnya masing-masing dan tidak mau dipindahkan di lokasi lain. Pemerintah sendiri dalam hal ini adalah PT. Angkasa Pura 1, sudah memberikan surat peringatan kepada masyarakat untuk segera meninggalkan rumahnuya. Seolah dianggap angin lalu, peringatan tersebut tidak diindahkan oleh mereka. Permasalahan ini tentu tidak bisa dibiarkan berlarut-larut, perlu adanya solusi untuk menjembatani kepentingan pemerintah dan masyarakat sendiri.

Guna menyelesaikan permasalahan ini, pemerintah sendiri telah melakukan berbagai proses komunikasi dengan masyarakat, seperti; sosialisasi, pendekatan kepada masyarakat, lobby dan negosiasi, membentuk opinion leader, serta membuat media-media komunikasi yang bertujuan untuk meningkatkan pemahaman masyarakat tentang perlunya pembangunan bandara baru. menjadi sebuah alternatif dalam hal ini.

Komunikasi di sini, berkaitan dengan percepatan proses pembangunan. Mengingat pembangunan bandara baru merupakan sebuah kebutuhan, dan proses komunikasi kepada masyarakat yang masih menentang menjadi sebuah keharusan. Komunikasi pembangunan sendiri adalah suatu ilmu yang dipelajari secara spesifik dalam penerapan konsep komunikasi dan teori yang digunakan dalam proses pembangunan. Menurut Nasution (2002), komunikasi pembangunan meliputi peran serta fungsi komunikasi (suatu interaksi pertukaran pesan secara dua arah) diantara semua pihak yang terlibat dalam usaha pembangunan, khususnya pemerintah dan masyarakat. Komunikasi perlu dilakukan dalam hal proses perencanaan, pelaksanaan, serta evaluasi terhadap pembangunan.

Dalam proses komunikasi pembangunan, hal terpenting yang perlu dilakukan untuk mensosialisasikan rencana pembangunan adalah menyampaikan pesan komunikasi dengan menarik dan mudah dipahami oleh masyarakat luas, sehingga akan adanya izin sosial dari masyarakat tanpa adanya tekanan/paksaan dari satu pihak. 


\section{Komunikasi Sosial Pembangunan}

Komunikasi merupakan ilmu yang multi disipilin. Komunikasi diperlukan dalam berbagai aspek kehidupan. Salah satunya adalah dalam ranah pembangunan. Dalam proses pembangunan tentu diperlukan adanya proses komunikasi baik kepada masyarakat luas ataupun kepada pihak terkait. Adanya komunikasi pembangunan dimaksudkan untuk memberikan pemahaman dan informasi tentang sejauh mana proses pembangunan itu

Page 142 diperlukan, bagaimana peran serta support dari berbagai pihak guna mensukseskan rencana pembangunan tersebut. Menilik definisi dari "komunikasi pembangunan" sendiri adalah suatu ilmu yang dipelajari secara spesifik dalam penerapan konsep komunikasi dan teori yang digunakan dalam proses pembangunan. Menurut Nasution (2002), komunikasi pembangunan meliputi peran serta fungsi komunikasi (suatu interaksi pertukaran pesan secara dua arah) diantara semua pihak yang terlibat dalam usaha pembangunan, khusunya pemerintah dan masyarakat. Komunikasi perlu dilakukan dalam hal proses perencanaan, pelaksanaan, serta evaluasi terhadap pembangunan.

Di dalam kaitannya dengan komunikasi pembangunan. Kita mengenal istilah komunikasi sosial pembangunan. Dimana dalam konteks pembangunan diperlukan adanya keselarasan antara aspek kemajuan lahiriah dan batiniah. Sehingga proses komunikasi pembangunan bisa berjalan dengan selaras dan menimbulkan kesepahaman bersama tanpa ada pihak yang merasa dirugikan. Dalam ilmu komunikasi dipelajari pula masalah proses, yakni proses penyampaian pesan dari komunikator kepada komunikan untuk merubah suatu pendapat, sikap, maupun perilaku. Oleh karenanya dalam pembangunan setidaknya juga melibatkan minimal 3 komponen, yakni: komunikator pembangunan (pemerintah, atau masyarakat), pesan pembangunan yang berisi gagasan atau ide atau program pembangunan, dan komunikan pembangunan (masyarakat luas sasaran dari pembangunan).

Pembangunan dalam konteks luas (negara) berarti sebuah proses pembangunan manusia seutuhnya yang bersifat pragmatik yang mampu memberikan inovasi-inovasi ataupun terobosan teknologi baik di masa kini, maupun di masa depan guna meningkatkan kesejahteraan masyarakat di suatu negara. Dalam konteks ini komunikasi menjadi sebuah kunci, guna merubah perilaku serta sikap manusia di suatu negara tersebut sebagai aktor utama dalam pembangunan, baik berperan sebagai subjek maupun objek pembangunan.

Pembangunan hanya akan tercapai apabila adanya peran dari masing-masing pihak yang terlibat. Pemerintah membuat perencanaan pembangunan, mensosialisasikan rencana pembangunan, dan melaksanakan pembangunan, harus didukung oleh masyarakat sebagai objek pembangunan tersebut. Tanpa adanya dukungan dari masyarakat, mustahil pembangunan bisa berjalan dengan efektif. Untuk mendapatkan dukungan dari masyarakat tersebut, tentu dibutuhkan pesan komunikasi pembangunan yang mudah dipahami oleh masyarakat luas. Pesan komunikasi tersebut, mengandung makna: pentingnya pembangunan, tujuan pembangunan, dan seberapa besar manfaat pembangunan tersebut. Dengan demikian nantinya masyarakat akan memahami arti penting dari sebuah pembangunan di suatu daerah.

Adanya konflik dengan masyarakat dalam rencana pembangunan, seperti: Pemerintah DIY dengan masyarakat Temon Kulon Progo dalam rencana pembangunan bandara baru (objek penelitian ini), PT. Semen Indonesia dengan masyarakat Kendeng di Rembang Jawa Tengah, Pemerintah DKI Jakarta dengan rencana Reklamasi Teluk Jakarta, maupun Pemerintah Bali dalam rencana reklamasi Teluk Benoa merupakan sebuah contoh bagaimana pesan komunikasi pembangunan tidak diterima baik oleh masyarakat. Strategi-strategi komunikasi dan pendekatan personal dari pemerintah kepada masyarakat diperlukan dalam hal ini, guna memberikan pemahaman tentang arti pentingnya pembangunan.

Arti penting strategi komunikasi dalam kaitannya dengan pembangunan di suatu negara ini dimaknai oleh Effendy (2010), mempunyai fungsi:

1. Menjembatani "cultural gab" akibat kemudahan yang diperoleh dan kemudahan dioperasionalkannya media massa yang begitu kuat pengaruhnya, dan jika dibiarkan akan merusak tataran budaya bangsa sendiri.

2. Mensosialisasikan pesan komunikasi yang bersifat informatif, persuasif, dan instruktif secara sistematik kepada sasaran guna memperoleh hasil yang optimal.

Dalam memilih strategi komunikasi yang tepat guna menyebarkan pesan-pesan pembangunan, pemilihan media juga menjadi suatu hal yang perlu diperhatikan oleh komunikator pembangunan. Guna memilih media komunikasi yang tepat, karakteristik 
Vol. 10 No. 2

November 2018

masyarakat maupun wilayah menjadi fokus utamanya. Masyarakat di daerah pedesaan tentu lebih efektif dengan media komunikasi yang konvensional ataupun komunikasi langsung. Sementara masyarakat di perkotaan akan lebih efektif dengan menggunakan media-media digital yang bisa diakses kapan dan dimana saja.

\section{METODE PENELITIAN}

Penelitian ini merupakan penelitian kuantitatif, yakni suatu prosedur penelitian yang memperoleh hasil berupa data-data numerik, sampel dari orang-orang atau perilaku yang diamati untuk menunjukkan berbagai fakta yang ada dan yang dilihat selama penelitian berlangsung.

Penelitian mengenai komunikasi sosial Pemerintah DIY dalam pembangunan bandara baru di Kulon Progo ini akan dilaksanakan dengan menggunakan metode survei. Menurut Kriyantono (2010), metode survei adalah suatu penelitian penjelasan terhadap peristiwa atau keadaan (explanation). Penelitian survei pada umumnya berkaitan dengan apa penyebab dan apa yang mempengaruhi suatu peristiwa atau keadaan yang ditimbulkan.

Sementara teknik pengambilan sampel dilakukan dengan teknik purposive sampling, yakni teknik pengambilan sampel dengan pertimbangan tertentu yang disesuaikan dengan tujuan penelitian ataupun berdasarkan pertimbangan tertentu. Nantinya akan dipilih elemen-elemen masyarakat yang mampu menjawab pertanyaan-pertanyaan dari peniliti terhadap obyek yang ingin diteliti (Erwan, 2011).

Adapun mengenai rumus yang digunakan untuk mengetahui besarnya sampel dalam penelitian ini, didapatkan dengan menggunakan cara Slovin. Dalam hal ini ukuran sampel merupakan sebuah berbandingan dari ukuran populasi dengan prosentase kelonggaran ketidaktelitian, di mana pengambilan sampel yang error masih dapat ditolerir/dipakai. Rumus ini sendiri memakai taraf kesalahan sebesar 5\%.

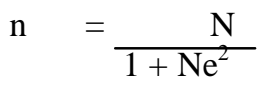

Keterangan:

$\mathrm{n} \quad \quad=$ jumlah sampel yang diambil

$\mathrm{N} \quad=$ jumlah populasi (masyarakat terdampak, di Temon Kulon Progo)

e $\quad=$ presentase kelonggaran ketidaktelitian karena

kesalahan pengambilan sampel $(5 \%)$

Berdasarkan rumus di atas, kemudian dapat dihitung besarnya jumlah sampel dalam penelitian ini:

$\mathrm{n} \quad=2449$

$$
\begin{aligned}
& \left.\overline{(1+2569} \times 0,05^{2}\right) \\
= & \frac{2449}{7,4225} \\
= & 329,94 \text { sampel }=330 \text { orang }
\end{aligned}
$$

Jadi jumlah sampel dalam penelitian ini adalah 330 orang. Sampel tersebut adalah masyarakat terdampak dari rencana pembangunan bandara baru di Kulon Progo.

\section{PEMBAHASAN}

\section{Efektivitas komunikasi pembangunan Pemerintah DIY dalam pembangunan bandara baru}

Efektivitas komunikasi pembangunan yang dilakukan Pemerintah DIY dalam pembangunan bandara baru di Kulon Progo ditunjukkan dengan analisis parametrik dan non parametrik, sebagai berikut: 
Hasil korelasi dengan product moment dari Pearson (analisis parametrik)

Page | 144

\begin{tabular}{|c|c|c|c|}
\hline \multicolumn{4}{|c|}{ Correlations } \\
\hline & & Perencanaan & Persepsi \\
\hline \multirow[t]{3}{*}{ perencanaan } & Pearson Correlation & 1 & $.641^{\prime \prime}$ \\
\hline & Sig. (2-tailed) & & .000 \\
\hline & $\mathrm{N}$ & 331 & 331 \\
\hline \multirow[t]{3}{*}{ persepsi } & Pearson Correlation & .641 & 1 \\
\hline & Sig. (2-tailed) & .000 & \\
\hline & $\mathrm{N}$ & 331 & 331 \\
\hline
\end{tabular}

${ }^{* *}$. Correlation is significant at the 0.01 level (2-tailed).

Berdasarkan hasil analisis di atas diketahui bahwa signifikansi antara perencanaan dan sosialisasi dengan persepsi masyarakat menunjukkan nilai $0.000(p<0.05)$. Hal ini memiliki arti bahwa terdapat hubungan yang signifikan antara perencanaan dan sosialisasi dengan persepsi masyarakat mengenai pembangunan bandara baru di Kulon Progo.

Hasil koefisien korelasi Spearman (analisis non parametrik)

\section{Correlations}

\begin{tabular}{|ccl|l|l|}
\hline \multirow{3}{*}{ Spearman's rho } & perencanaan & Correlation Coefficient & perencanaan & persepsi \\
& & 1.000 & .601 \\
& & Sig. (2-tailed) &. & .000 \\
& $\mathrm{~N}$ & 331 & 331 \\
\cline { 2 - 5 } & persepsi & Correlation Coefficient & .601 & 1.000 \\
& & Sig. (2-tailed) & .000 &. \\
& $\mathrm{~N}$ & 331 & 331 \\
\hline
\end{tabular}

**. Correlation is significant at the 0.01 level (2-tailed).

Berdasarkan hasil analisis di atas diketahui bahwa signifikansi antara perencanaan dan sosialisasi dengan persepsi masyarakat menunjukkan nilai $0.000(p<0.05)$. Hal ini memiliki arti bahwa terdapat hubungan yang signifikan antara perencanaan dan sosialisasi dengan persepsi masyarakat mengenai pembangunan bandara baru di Kulon Progo.

Dari hal tersebut, dapat ditarik benang merah bahwa proses perencanaan telah dilakukan dengan baik oleh pemerintah Kulon Progo, sehingga proses komunikasi pembangunan yang dijalankanpun telah berhasil untuk memberikan pemahaman kepada masyarakat tentang pentingnya bandara baru di Yogyakarta ini. Hal ini dapat dilihat dari pertanyaan peneliti terkait dengan proses perencanaan pembangunan bandara baru yang dilakukan pemerintah, sebagai berikut. 
Kuesioner 1.

Perencanaan pembangunan Bandara Baru di Kulonprogo, dilakukan dengan baik

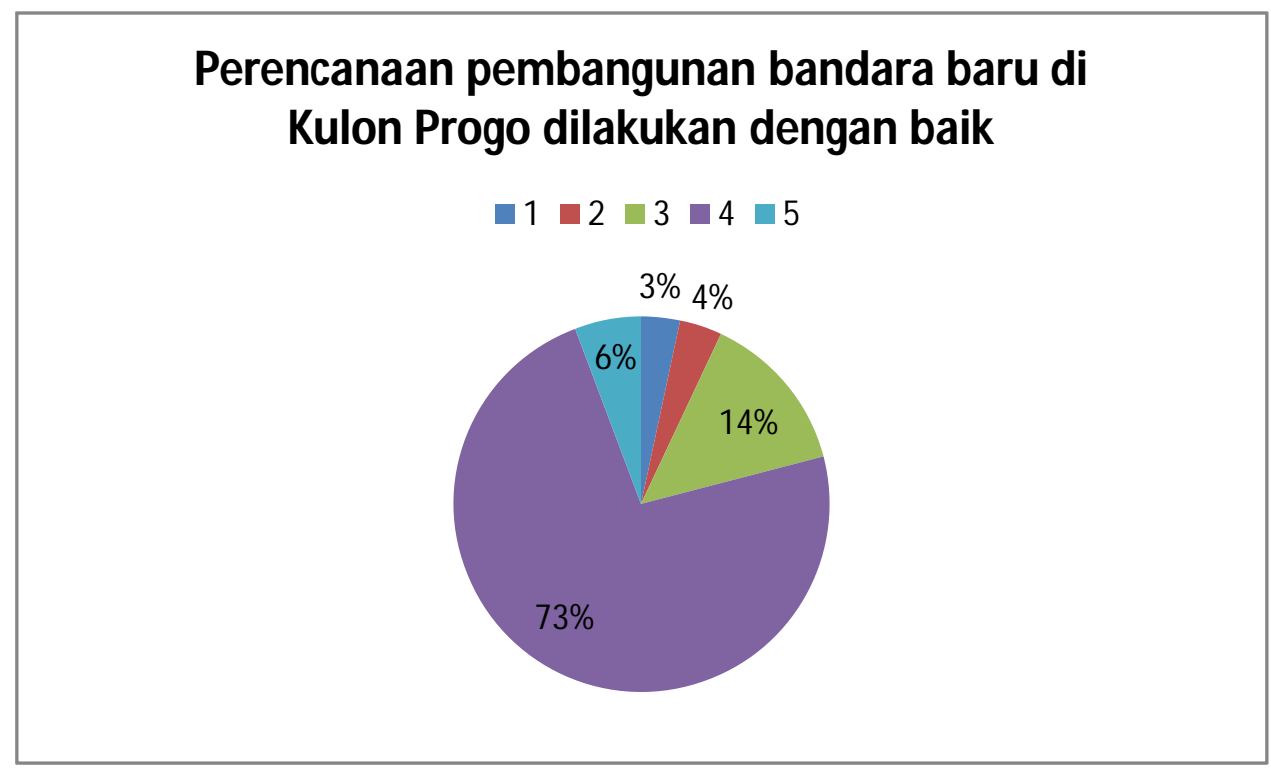

Bedasarkan diagram di atas, diperoleh data bahwa masyarakat yang memilih opsi Sangat Tidak Setuju (1) ada 11 orang (3\%), Tidak Setuju (2) ada 12 orang (4\%), Kurang Setuju (3) ada 46 orang (14\%), Setuju (4) ada 242 orang (73\%), dan Sangat Setuju (5) ada 19 orang (6\%) dari total 330 responden yang mengisi kuesioner. Mayoritas dari responden menyatakan setuju bahwa perencanaan pembangunan bandara baru dilakukan pemerintah dengan baik, yakni sebesar $(73,33 \%)$ atau 242 responden.

Selanjutnya ketika masyarakat diberikan pertanyaan terkait dengan proses sosialisasi yang dilakukan pemerintah terkait dengan pembangunan bandara baru ini berlangsung dengan baik, sebagaimana kuesioner di bawah ini. 
Kuesioner 2.

Sosialisasi terkait dengan rencana pembangunan bandara baru kepada masyarakat, dilakukan dengan baik

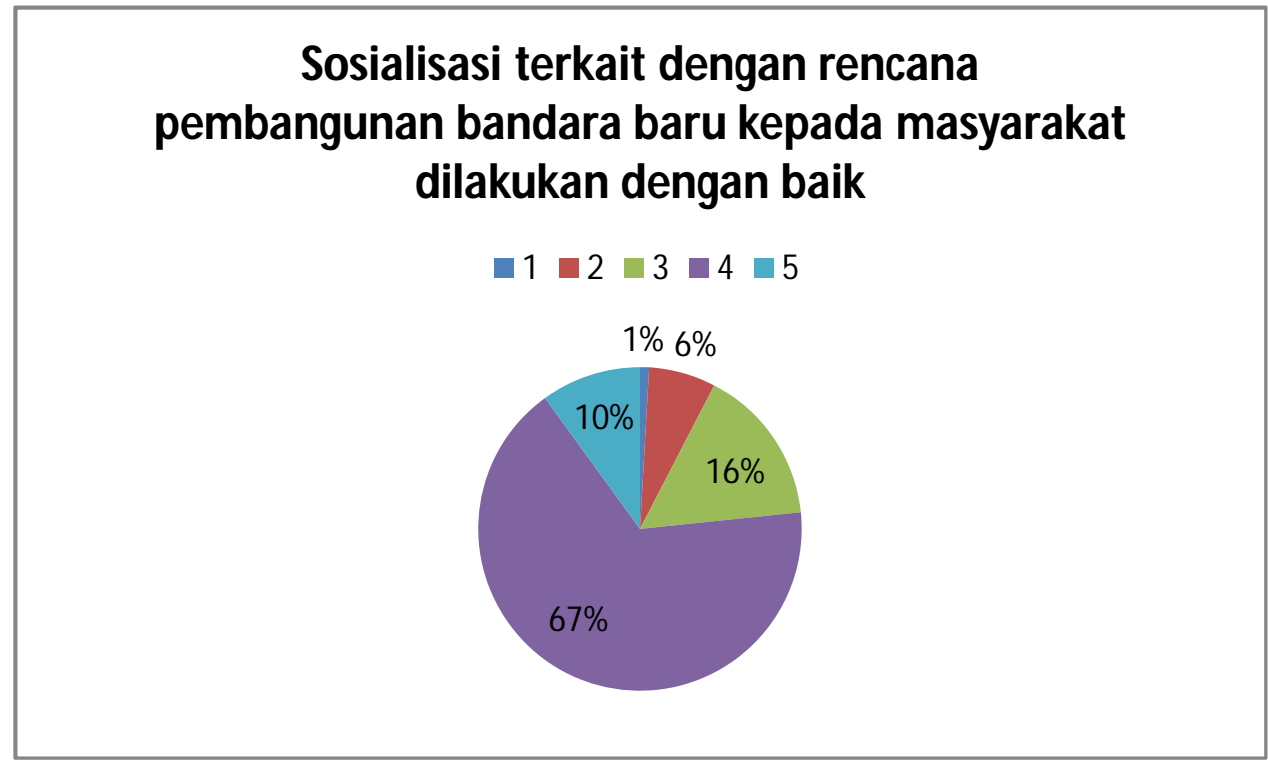

Dari diagram di atas, diperoleh data bahwa masyarakat yang memilih opsi Sangat Tidak Setuju (1) ada 3 orang (1\%), Tidak Setuju (2) ada 22 orang (6\%), Kurang Setuju (3) ada 52 orang (16\%), Setuju (4) ada 220 orang (67\%), dan Sangat Setuju (5) ada 33 orang (10\%) dari total 330 responden yang mengisi kuesioner. Dari data tersebut dapat disimpulkan bahwa mayoritas $(67 \%+10 \%)$ masyarakat setuju dan sangat setuju dengan pernyataan sosialisasi terkait dengan rencana pembangunan bandara baru kepada masyarakat dilakukan dengan baik.

Berdasarkan analisis peneliti, hal tersebut merupakan hasil dari usaha pemerintah yang memang selama ini sangat intens berkomunikasi dengan masyarakat untuk memberikan pemahaman terkait rencana pembangunan bandara baru ini. Proses sosialisasi dan komunikasi yang dilakukan pemerintah dilakukan beberapa kali, bahkan pemerintah tidak segan-segan melakukan strategi door to door yakni mendatangi rumah-rumah masyarakat untuk melakukan sosialisasi. Pemerintah juga senantiasa terbuka dalam menerima aspirasi, pertanyaaan, dan keluhan dari masyarakat dalam proses pembangunan bandara baru ini.

Saat ini mayoritas masyarakat telah memberikan dukungan kepada pemerintah untuk segera menyelesaikan proses pembangunan bandara baru di Kulon Progo tersebut. Tantangan selanjutnya adalah bagaimana pemerintah merealisasikan stakeholder expectations dari bandara baru ini. Mengingat tentunya masyarakat tentu mempunyai harapan besar tentang adanya peningkatkan kualitas hidup ataupun kesejahteraan mereka dengan adanya bandara baru ini.

\section{Persepsi masyarakat dalam pembangunan bandara baru}

Di dalam penelitian ini, peneliti berhasil menggali berbagai persepsi masyarakat, terkait dengan pembangunan bandara baru ini. Adapun beberapa persepsi masyarakat di Temon Kulon Progo diantaranya, sebagai berikut:

- Bandara baru dan peningkatan perekonomian masyarakat

Mayoritas dari masyarakat terdampak mempunyai harapan agar dengan adanya pembangunan bandara di Temon Kulon Progo ini bisa meningkatkan perekonomian mereka. Peningkatan perekonomian tersebut, diantaranya; adanya prioritas bagi masyarakat sekitar untuk dapat bekerja di bandara dengan berbagai kemampuan yang ada, adanya kemudahan/kompensasi yang didapatkan masyarakat tidak hanya saat proses pembangunan sedang berjalanan saja melainkan juga ketika bandara sudah mulai beroperasi, adanya 
Vol. 10 No. 2

November 2018

pengembangan usaha kecil dan menengah bagi masyarakat sekitar guna mewujudkan kemandirian bagi masyarakat pasca mereka kehilangan lahan untuk bercocok tanam.

Hal tersebut sebenarnya bisa dipahami, bahwa bagi masyarakat terdampak mereka tentunya menginginkan adanya kebermanfaatan terkait dengan pembangunan bandara baru ini. Masyarakat di Temon telah banyak berkorban untuk mensukseskan pembangunan bandara ini, mereka kehilangan rumah, tanah, ternak, lahan pertanian untuk mewujudkan program pemerintah dengan adanya pembangunan bandara baru ini.

Oleh karenanya, upaya-upaya untuk pengembangan masyarakat di Temon Kulon Progo sangat diperlukan untuk mendukung keberlanjutan pembangunan bandara baru itu sendiri. Mengingat dalam konsep komunikasi pembangunan, sebagaimana yang disampaikan oleh Harun dan Ardianto (2011), bahwa komunikasi pembangunan akan berhasil apabila ada pembinaan ataupun mekanisme terhadap keikutsertaan khalayak sebagai pelaku pembangunan itu sendiri, dalam proses pembangunan baik dari saat perencanaan, pelaksanaan, maupun evaluasi.

Adanya perhatian dan pembinaan secara berkelanjutan bagi masyarakat terdampak memang menjadi hal yang perlu diperhatikan oleh pemerintah. Hal ini bertujuan untuk mendukung keberlanjutan pembangunan bandara baru. Mengingat pembangunan bandara ini bukan merupakan proses yang singkat, namun akan terus berlangsung seiring dengan upaya-upaya pengembangannya. Dukungan dari masyarakat dalam setiap program pengembangan tentu sangat dibutuhkan. Saat ini masyarakat mungkin telah menerima rencana pembangunan bandara ini dengan kesediaan mereka untuk direlokasi di tempat lain, akan tetapi apakah di masa-masa mendatang masyarakat masih tetap akan menerima? Tentu hal tersebut merupakan hal yang belum bisa dijawab saat ini. Hanya saja upaya-upaya untuk senantiasa mendapatkan dukungan dari masyarakat baik di waktu sekarang, maupun di hari-hari mendatang perlu dilakukan. Salah satu upaya yang bisa dilakukan adalah dengan senantiasa menjadi pendengar yang baik atas setiap keluhan/aspirasi dari masyarakat sekitar, serta berupaya untuk memberikan kebermanfaatan sebagai upaya timbal balik atas beroperasinya bandara baru tersebut.

- Pembangunan bandara baru supaya segera selesai

Proses pembangunan bandara baru saat ini memang tengah dilakukan. Meskipun beberapa kelompok masyarakat masih saja ada yang tidak setuju, akan tetapi hal tersebut bukan merupakan sebuah kendala bagi pemerintah untuk melaksanakan pembangunan bandara baru ini. Peneliti telah membagikan kuesioner kepada 330 warga terdampak, dari hasil tersebut 212 masyarakat (64\%) masyarakat menjawab setuju apabila proses pembangunan bandara baru ini bisa berjalan dengan lancar dan segera selesai.

Hal ini nampaknya merupakan buah dari strategi komunikasi pemerintah yang selama ini memang dilakukan secara intens, baik melalui media komunikasi, maupun secara langsung. Komunikasi tersebut telah memberikan hasil adanya pemahaman masyarakat terkait dengan urgensi dari pembangunan bandara baru ini. Masyarakat memahami bahwa memang pada dasarnya pembangunan bandara baru saat ini menjadi sebuah kebutuhan untuk meningkatkan pariwisata di Yogyakarta sendiri, untuk mengakomodir jumlah penumpang pesawat yang setiap tahunnya mengalami peningkatan.

Jika di awal masyarakat banyak melakukan penolakan terhadap pembangunan bandara baru ini, maka sekarang mayoritas dari mereka telah setuju dan bahkan mendukung program pembangunan bandara baru ini. Dalam hal ini dapat diartikan bahwa masyarakat telah mampu mengetahui tujuan komunikasi pembangunan itu sendiri. Dimana komunikasi pembangunan hendaknya dapat memberikan informasi, mengubah perilaku, mampu menggugah perasaan, mengubah pendapat ataupun opini untuk mewujudkan partisipasi masyarakat serta meningkatkan pendapatan. Adanya perubahan di masyarakat maupun perubahan sosial (social change) juga merupakan tujuan dari komunikasi pembangunan ini.

Menurut Nasution (2007), tujuan komunikasi pembangunan akan berhasil apabila adanya adanya persamaan misi, mengkomunikasikan ide-ide serta program penggunaan kepada khalayak yang menjadi sasaran ataupun yang dimaksudkan kelak sebagai penerima manfaat kegiatan yang bersangkutan.

Senada dengan hal di atas, saat ini masyarakat telah dapat memahami maksud dan tujuan dari pembangunan bandara baru di Kulon Progo. Sekarang masyarakat sangat berharap agar 
pembangunan bandara baru ini dapat segera selesai dilakukan. Dengan demikian masyarakat nantinya dapat segera menikmati kebermanfaatan adanya pembangunan baru ini, seperti adanya industri rumah tangga yang tumbuh subur di sekitar bandara, terserapnya sumber daya manusia untuk pengelolaan bandara baru, serta adanya kemudahan-kemudahan yang diperoleh bagi masyarakat sekitar untuk menggunakan bandara baru nantinya.

Dalam konteks komunikasi pembangunan, apabila proses komunikasi telah dilakukan untuk Page|148 mensosialisasikan arti penting pembangunan tersebut kepada masyarakat, maka langkah selanjutnya adalah pelaksanaan pembangunan tersebut. Pelaksanaan pembangunan semestinya dapat dijalankan dengan baik, tepat waktu, transparan, dan sesuai dengan perencanaan yang dibuat. Apabila pembangunan tersebut dapat dilaksanakan dengan baik, maka akan baik pula persepsi masyarakatnya. Jika tidak, bukan tidak mungkin pergerakan sosial di masyarakat akan dapat tumbuh kembali untuk menuntut janji-janji pemerintah guna meningkatkan kesejahteraan masyarakat dengan adanya pembangunan bandara baru ini.

- Adanya transparansi dalam pengambilan kebijakan pembangunan bandara baru

Di era keterbukaan informasi seperti sekarang ini, adanya transparansi atas berbagai kebijakan yang diambil pemerintah menjadi suatu kewajiban yang harus dilakukan. Dari kuesioner yang peneliti bagikan kepada 330 masyarakat yang tersebar di berbagai desa di Temon Kulon Progo, 223 (68\%) masyarakat menyatakan bahwa proses pengukuran dan ganti rugi dilakukan dengan baik, cepat dan terbuka.

Prinsip transparansi (keterbukaan) inilah yang seharusnya senantiasa dipegang teguh pemerintah dalam konteks pembangunan. Agar jangan sampai masyarakat merasa ditipu/dirugikan atas rencana pembangunan dengan tidak adanya komunikasi yang bersifat dua arah. Komunikasi memang menjadi tonggak penting dalam mendukung kesuksesan pembangunan. Dengan adanya komunikasi yang efektif maka komunikan (masyarakat) akan dapat memahami arti penting dan tujuan pembangunan itu sendiri, sehingga akan adanya perubahan sikap dan perilaku mereka untuk mendukung rencana pembangunan. Perubahan sikap dapat terjadi apabila adanya kepercayaan dari masyarakat. Oleh karenya tugas pemerintah adalah untuk senantiasa menjaga kepercayaan dari masyarakat, terkait dengan harapan mereka terhadap pembangunan bandara baru ini.

Mengenai transparansi (keterbukaan) yang diinginkan oleh masyarakat, diantaranya adalah; keterbukaan sampai kapan proses pembangunan bandara ini selesai, sejauhmana perkembangannya, pendanaannya, serta bagaimana kompensasi/timbal balik yang diberikan oleh pemerintah kepada masyarakat.

Di era keterbukaan informasi publik seperti sekarang ini, telah adanya jaminan dari pemerintah untuk mendapatkan informasi yang akurat dan detail terkait dengan pengelolaan lembaga publik. Oleh karenanya, masyarakat sendiri tidak perlu khawatir untuk tidak mendapatkan informasi yang diinginkan terkait dengan pembangunan bandara baru ini.

Pemerintah Kulon Progo sendiri, melalui Dinas Kominfo telah membangun Media Center yang bertujuan untuk memberikan informasi kepada stakeholders, baik masyarakat maupun media. Dengan adanya Media Center yang dibangun oleh Pemerintah Kupon Progo tersebut diharapkan dapat terwujudnya komunikasi dua arah yang saling bersinergi antara pemerintah sebagai komunikator pembangunan, dan masyarakat sendiri sebagai komunikan pembangunan.

Apresiasi begi pemerintah tentu perlu diberikan akan kinerjanya untuk menanggapi setiap keluhan dan pertanyaan dari masyarakat luas terkait dengan rencana pembangunan bandara baru ini. Hanya saja upaya-upaya untuk memaksimalkan fungsi Media Center juga perlu dilakukan. Berdasarkan data yang peneliti peroleh bahwa masyarakat masih banyak yang menyatakan bahwa mereka kurang puas dengan pelayanan yang diberikan di media center, yakni sebesar 39\% atau 128 masyarakat, sedangkan yang menjawab puas sebesar 33\% atau 109 masyarakat. Hal ini menunjukkan bahwa masyarakat masih banyak yang kurang puas dengan pelayanan yang diberikan di Media Center. Ketika peneliti mengejar dengan pertanyaan lanjutan mengenai mengapa masyarakat merasa kurang puas? Mayoritas dari mereka menjawab bahwa informasi yang diberikan banyak yang tidak disampaikan dengan detail, sehingga harapan mereka untuk mendapatkan informasi yang dibutuhkan pun menjadi kurang terpenuhi.

Kebutuhan akan informasi tentu menjadi kebutuhan bagi masyarakat terdampak, terlebih saat proses pengukuran tanah, relokasi, maupun pembayaran ganti rugi yang dilakukan. 
Masyarakat tentu menginginkan proses tersebut bisa berjalan dengan cepat sesuai dengan harapan mereka. Oleh karenya komunikasi yang efektif dan bersifat dua arah, dan bisa dilakukan kapan dan dimana saja menjadi sebuah keharusan yang perlu dilakukan. Walaupun sekarang ini proses tersebut sudah berjalan, namun proses evaluasi tentu perlu dilakukan untuk memaksimalkan proses pembangunan di waktu mendatang.

\section{KESIMPULAN}

Setelah melakukan pengumpulan data, dan melakukan analisis, peneliti dapat menarik beberapa kesimpulan dalam penelitian ini sebagai berikut.

- Adanya hubungan yang signifikan antara perencanaan dan sosialisasi dengan persepsi masyarakat mengenai pembangunan bandara baru di Kulon Progo. Proses perencanaan yang dilakukan secara matang, dan komunikasi yang dilakukan dengan intens dan terbuka telah memberikan hasil adanya persepsi yang baik dari masyarakat terkait dengan rencana pembangunan bandara baru di Temon Kulon Progo ini.

- Dari adanya signifikansi hubungan tersebut, maka dapat dikatakan bahwa proses komunikasi pembangunan yang dilakukan pemerintah kepada kelompok "Wahana Tri Tunggal" berjalan dengan efektif, dan memberikan hasil adanya dukungan dari masyarakat terkait dengan pembangunan tersebut. Masyarakat yang tadinya menolak keras rencana pembangunan bandara ini, sekarang sudah berbalik arah dan memberikan dukungan terhadap pemerintah untuk menyelesaikan pembangunan bandara baru ini. Hanya tinggal sedikit saja masyarakat yang masih bersikukuh menolak pembangunan bandara baru, yakni sekitar $10 \%$ (116 kepala keluarga).

- Masyarakat mempunyai berbagai harapan terkait dengan pembangunan bandara baru ini, diantaranya: bandara baru diharapkan dapat segera diselesaikan, dan mampu meningkatkan perekonomian masyarakat. Adanya prioritas bagi masyarakat sekitar untuk mendapatkan lapangan pekerjaan di bandara baru kelak menjadi harapan utama dari masyarakat. Selain itu masyarakat juga menginginkan adanya transparansi dari pemerintah terkait dengan berbagai kebijakan yang akan diambil pemerintah dalam setiap perencanaan/pengembanganan bandara baru ke depannya. Masyarakat sebagai obyek dari pembangunan tentu menghendaki adanya komunikasi dua arah yang saling menguntungkan antara pembangunan dengan pemberdayaan masyarakat sekitar.

\section{DAFTAR PUSTAKA}

Doyle, Gillian. (2002). Media Ownership. London: Sage Publications

Effendy, Onong Uchjana. (2010). Peranan Komunikasi Massa dalam Pembangunan. Yogyakarta : Gadjah Mada University

Harun, H. Rochajat. (2008). Komunikasi Pembangunan dan Perubahan Sosial. Jakarta : Grafindo

Iriantara, Yosal. (2004). Community Relations. Bandung : Simbiosa Rekatama

Kadir, Kasali, Rhenald. (2008). Manajemen Public Relations. Jakarta : Pustaka Grafiti Utama

Kriyantono, Rachmat. (2010). Teknik Praktis Riset Komunikasi. Disertai Contoh Praktis Riset Media Public Relations, Advertising, Komunikasi Organisasi, Komunikasi Pemasaran. Jakarta : Kencana Prenada Media Group

Nasution, Zulkarnaen. (2002). Komunikasi Pembangunan, Pengenalan Teori dan Penerapannya. Jakarta : PT Raja Grafindo Persada

Suyanto, M. (2003). Multimedia: Alat untuk Meningkatkan Keunggulan Bersaing. Yogyakarta : Andi 
Page | 150 
Vol. 10 No. 2

November 2018

Page | 151 